\title{
REKONSTRUKSI KETIDAK ADILAN GENDER MELALUI PENDIDIKAN ISLAM
}

\author{
Mohammad Fahrur Rozi \\ Universitas Madura Pamekasan \\ e-mail: mofahroz@gmail.com
}

\begin{abstract}
Abstrak: Diskriminasi dalam kesetaraan gender merupakan sumber masalah dalam struktur kehidupan sosial yang disebabkan oleh budaya patriarkhis yang hampir terjadi pada seluruh lapisan masyarakat di dunia. Mengingat Islam merupakan agama rahmatan lil 'alamin yang dapat dijadikan sebagai petunjuk bagi seluruh umat manusia, maka sepatutnya pendidikan Islam ikut andil didalamnya untuk memerangi ketidakadilan gender. Dengan berdasarkan al-Qur'an dan tafsir ayat-ayat gender diharapkan mampu meminimalisir kesalahpahaman tentang makna gender yang sebenarnya.
\end{abstract}

Kata Kunci: Ketidakadilan Gender, Pendidikan Islam

Abstract: Discrimination in gender equality is a source of problems in structure of social life and can be caused by patriarchal culture that almost occurs in all walks of life in the world. Considering that, Islam is religion as a rahmatan lil 'alamin that can be used as a guide for all humanity, it is fitting that Islamic education contributes it to combat gender injustice. Based on the Qur'an and interpretation of gender verses, it is expected to minimize misunderstandings about the true meaning of gender.

Keywords: gender injustice, Islamic Education

\section{Prolog}

Seiring perkembangan science dan teknologi yang semakin maju, memiliki dampak dalam berbagai aspek kehidupan manusia, meliputi ekonomi, budaya, sosial, pendidikan dan aspek lainnya. Akan tetapi manusia hidup tidak akan pernah lepas dan luput dari berbagai macam problema dan polemik dalam kehidupannya.Indonesia, misalnya merupakan Negara yang berkembang-yang notabane masyarakatnya hidup dalam tatanan konsep pluralis dan multikulturalis dalam berinteraksi baik dalam satu suku dengan suku yang lain, bahasa satu dengan bahasa lainnya.

Terlepas dari itu semua, ketimpangan dan ketidakadilan dalam tatanan sosial, profesi, bahkan dalam pendidikan sekalipun terjadi kebiasan dan ketidakadilan dalam gender.Mayoritas orang awam dan (sebagian masyarakat pedesaan yang berpendidikan rendah), menganggap bahwa

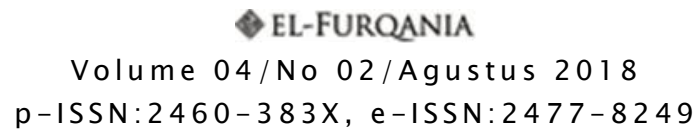


kehidupan anak perempuan hanya berposisikan sebagai istri yang tugasnya mengurus anak, memasak, dan mengerjakan pekerjaan rumah lainnya (rumah, sumur dan kasur).Namun pada hakikatnya itu merupakan tugas istri yang sudah dikodratkan oleh Allah swt-walaupun tidak menutup kemungkinan, seorang perempuan atau istri dapat membantu menopang pekerjaan suami dengan berdagang di pasar, membuka usaha seperti toko, warung nasi, petani dan profesi lainnya.

Dalam aspek pendidikan, yang sering menjadi ketua kelas dan ketua OSIS adalah laki-laki ketimbang perempuan. Hal ini diasumsikan bahwa laki-laki lebih tegas dalam bertindak dan bijaksana dalam mengambil keputusan, terlebih lagi didasarkan pada ayat: "Bahwa suamimerupakan pemimpin bagi istrinya". Persoalan inilah yang kemudian melemahkan pemahaman sosial tentang kesetaraan dan keadilan gender dalam kehidupan masyarakat dan akhirnya menempatkan dan meletakkan derajat perempuan lebih rendah dari pada laki-laki (sub-ordinasi).

Islam adalah agama ya'lüwa lā yu'là 'alaih yang menjunjung tinggi nilai-nilai kemanusian serta persamaan hak dan kewajibannya. ${ }^{2}$ Feminisme

\footnotetext{
1 "Para suami mempunyai satu tingkatan kelebihan daripada istrinya...." (QS. AlBaqarah [2]: 228). "Kaum laki-laki adalah pemimpin bagi kaum wanita, karena Allah telah melebihkan sebagian mereka (laki-laki) atas sebagian yang lain (wanita), dan karena mereka (laki-laki) telah menafkahkan sebagian dari harta mereka...." (QS. Al-Nisā' [4]: 34). "Dan para wanita mempunyai hak yang seimbang dengan kewajibannya menurut cara yang ma'rüf. Akan tetapi para suami mempunyai satu tingkat kelebihan daripada istrinya" (QS. Al-Baqarah [2]: 228). Tidaklah laki-laki itu (sama) seperti perempuan (QS. Ali-Imrān [3]: 36)Walaupun ayat di atas menjelaskan bahwa laki-laki memiliki peran dan tugas yang lebih berat dan lebih tinggi derajatnya, tidak menutup kemungkinan dalam menentukan kebijkan dan menyelesaikan masalah lebih didominasi oleh laki-laki. Oleh karena itu,Muhibbin Syah menjelaskan bahwa otak merupakan pusat segala perkembangan kognitif pada setiap manusia, karena otak merupakan segala sumber dan sekaligus pengendali ranah afektif (rasa), dan ranah psikomotor (karsa). Muhibbin Syah. Psikologi Pendidikan dengan Pendekatan Baru(Bandung: PT.Remaja Rosda Karya, 2011), 65.

${ }^{2} \mathrm{Al}$-Qur'an memberikan bukti yang nyata bahwa wanita benar-benar setara dengan pria di mata Tuhan dalam hal hak dan kewajibannya. Dalam al-Qur'an dinyatakan: "Tiap-tiap diri bertanggung jawab atas apa yang telah diperbuatnya." (QS. AlMumtahanah [60]: 38) "Maka Tuhan mereka memperkenankan permohonannya (dengan berfirman): "Sesungguhnya Aku tidak menyia-nyiakanamal orang-orang yang beramal di antara kamu, baik laki-laki atau perempuan, (karena) sebagian kamu adalah turunan dari sebagian yang lain." (QS.Al-Imran [3]: 195) "Barangsiapa yang mengerjakan amal saleh, baik laki-laki maupun perempuan dalam keadaan beriman, maka sesungguhnya akan Kami berikan kepadanya kehidupan yang baik, dan sesungguhnya akan Kami beri balasan kepada mereka
} 
merupakan paham yang dilahirkan karena ketidakpuasan dan deskriminasi kaum perempuan untuk memperjuangkan hak-haknya dan mencapai kesetaraan gender dengan kaum pria dan seakan-akan menghilangkan karakteristik perempuan dengan naluri keibuannya yang lemah lembut sekaligus menjadi fitrah perempuan yang dibawa sejak lahir. ${ }^{3}$

Pendidikan Islam merupakan proses yang dilakukan untukmenciptakan manusia seutuhnya, beriman dan bertakwa kepada Tuhanserta mampu mewujudkan eksistensinya sebagai khalifah Allah dimuka bumi,yang berdasarkan ajaran al-Qur'an dan sunnah, maka tujuan dalam konteks iniberarti terciptanya insan-insan kamil setelah proses pendidikan berakhir. ${ }^{4}$

Pendapat al-Qābisi $\bar{s}^{5}$ yang menakjubkan tentang perhatiannya di bidang pendidikan - salah satunya adalah anak-anak yang masuk di Kuttāb tidak ada perbedaan derajat atau martabat.Menurut beliau, pendidikan adalah hak semua orang tanpa ada pengecualian dan perbedaan apapun.Beliau mengehendaki agar penyelenggaraan pendidikan anak-anak muslim dilaksanakan dalam satu tempat, dan memperoleh pengetahuan dari pendidik (guru) yang satu. Perhatian al-Qābisì terhadap pendidikan anak tersebut bukan saja hanya tertuju padaanak laki-laki, akan tetapi pendidikan bagi anak perempuan menurutnya merupakan suatu keharusan, sama dengan pendidikan anak laki-laki. ${ }^{6} \mathrm{Oleh}$ karena itu, penulis ingin merekonstruksi

dengan pahala yang lebih baik dari apa yang telah mereka kerjakan.”(QS. Al-Nahl [16]: 97).

${ }^{3}$ Feminisme adalah suatu kesadaran akan penindasan dan pemerasan terhadap perempuan dalam masyarakat, di tempat kerja dan dalam keluarga, serta tindakan sadar oleh perempuan maupun laki-laki untuk mengubah keadaan tersebut.Ilyas, Feminisme dalam Kajian Tafsir al-Qur'an Klasik dan Kontemporer (Yogyakarta: Pustaka Pelajar, 1998), 40.

${ }^{4}$ Hery Noer Aly, Ilmu Pendidikan Islam, (Jakarta: Logos Wacana Ilmu, 1999), 5.

${ }^{5}$ Sosok yang amat cinta terhadap ilmu pengetahauan, al-Qābisi pernah merantau ke beberapa negara Timur Tengah, seperti Hijāz dan Mekah untuk menunaikan ibadah haji sekaligus menuntut ilmu. Selain itu, Ia juga pernah tinggal di Mesir beberapa waktu lamanya, dan berguru pada salah seorang ulama di Iskandariyah. Ia memperdalam ilmu agama, dan hadis dari ulama-ulama terkemuka, di antaranya; A $\bar{i}$ Ibn Zaid al-Iskandarì, seorang ulama yang masyhur dalam meriwayatkan hadis Imam Mālik dan mendalami mazhab fiqhinya. Selain itu, ia juga memperdalam ilmu agama dan hadis dari ulama-ulama yang terkenal di Afrika Utara, seperti Abū al-'Abbās al-Ibyānì, Abū Hasan ibn Masrūf al-Dhigbaghī, Abū Abdillah ibn Masrūr al-Aṣa îi, Ziyad ibn Yūnus al-Yasabī, Alì al-Dibāgh, dan Abdullāh bin Abì Zaìd, dan sebagainya. Abuddin Nata, Pemikiran Para Tokoh Pendidikan Islam: Kajian Filsafat Pendidikan Islam (Cet. II; Jakarta: PT Raja Grafindo Persada, 2001), 26.

${ }^{6}$ Muhammad Munir Mursi, al-Tarbiyah al-Islāmiyah Usūluhā wa Tatawwuruhā fí al-Bilād al-Arabiyah, Cet. IV (Mesir: Dār al-Ma'ārif, 1987), 120. 
ketidakadilan gender melalui pendidikan Islam dalam memerangi pemahaman orang awam dan budaya patriarkhis tentang perempuan.

\section{Hakikat Manusia dalam Pendidikan Islam}

Pada hakikatnya, pendidikan Islam merupakan usaha mengantarkan manusia menjadi manusia yang sempurna (insān al-kāmil) secara menyeluruh (holistic) dengan cara latihan, bimbingan dalam segala aspek kehidupan (hablu minallāh wa hablu min al-nās) berdasarkan nash-nash alQur'an dan hadis demi tercapainya kehidupan dan kebahagian di dunia dan akhirat.

Para cendekiawan muslim, memberikan berbagai macam istilah unt uk memahami makna pendidikan Islam. Al-Ațtās menggunakan istilah ta'dib dalam memahami konsep pendidikan Islam, al-Nahlawi dengan konsep tarbiyah dan Abdul Fatah Jalāl dengan konsep ta'limnya. Terlepas dari ketiga definisi tersebut, pendidikan Islam diharapkan mampu melahirkan manusia yang memberikan manfaat pada dirinya, orang lain, masyarakat, agama berbangsa dan bernegara. Untuk mencapai itu semua, maka Islam menganjurkan kepada seluruh umat manusia untuk mempelajari ilmu pengetahuan, baik laki-laki maupun perempuan, muda ataupun tuasebagaimana yang telah dijelaskan dari beberapa hadist nabi Muhammad saw. Islam tidak hanya mewajibkan pemeluknya untuk mempelajari ilmu agama, namun juga ilmu-ilmu yang lain, seperti ilmu jiwa dan ilmu alam (Q.S. Fushshilat/41: 53), sejarah (Q.S. Muhammad/47: 10), botani (Q.S. 'Abasa/80: 24-32, Q.S. al-Hajj/22: 5, Q.S. Yasin/36: 36 dan Q.S. alMu'miniun/23: 18-20), zologi (Q.S. al-Ghasyiyah/88: 17, Q.S. al-Mulk/67: 19 dan Q.S. Fatir/35: 12), perkembangan dan proses kejadian manusia dan alam (Q.S. al-Anbiya'/21:30, Q.S. al-Mu'minun/23: 12-14, Q.S. an-Nur/24: 45 dan Q.S. Fushshilat/41: 11, ilmu falak (astronomi) (Q.S.Yasin/36: 37-40 dan Q.S. Āli 'Imran/3: 190-191), matematika (Q.S. Yasin/36: 12, Q.S. alJinn/72: 23, Q.S. al-Kahfi/18: 49, Q.S. al-Hijr/15: 19 dan 21 dan Q.S. alQamar/54: 49, fisika dan kimia (Q.S. al-Hadid/57: 25, Q.S. al-Kahfi/18: 9697, Q.S. ar-Ra'd/13: 12-13), geologi dan geografi (Q.S. az-Dzariyat/51: 20-

\footnotetext{
7 Al-Rasyidin, Falsafah Pendidikan Islami: Membangun Kerangka Ontologi, Epistimologi

dan Aksiologi Praktik Pendidikan (Bandung: Citapustaka Media Perintis, 2008), 107.

${ }^{8}$ Rasulullah Saw. Telah bersabda: Menuntut ilmu adalah wajib bagi setiap muslim dan orang yang meletakkan ilmu kepada orang yang bukan ahlinya (orang yang enggan untuk menerimanya dan orang yang menertawakan ilmu agama) seperti orang yang mengalungi beberapa babi dengan beberapa permata, dan emas. (HR. Ibnu Mājah). Hadits Riwayat Sunan Ibnu Mājah, Kitab al-'Ilmi, Bab Keutamaan Ulama’ dan Anjuran Mencari Ilmu (t.t.: Dār al-Fikri 2001) Jilid 1. 183.
} 
21, Q.S. an-Nur/24: 43, Q.S. ar-Rum/30: 22, Q.S. Saba'/34: 12, Q.S. Fatir/35: 27 dan tentang manusia serta alam (Q.S. an-Nah1/16: 3-17).

Berdasarkan ayat di atas dapat dipahami bahwa seluruh umat muslim dituntut (wajib) mencari ilmu pengetahuan tanpa memandang suku, agama, ras dan antar golongan (SARA) dan persamaan dalam menuntut ilmu, dan tanpa diskriminasi gender dan strata sosial dalam mempersiapkan kehidupan yang dinamis dan berkesinambungan ${ }^{10}$ dalam keluarga, masyarakat dan bernegara.

\section{Ketidakadilan Gender dalam Kontek ke-Indonesiaan}

Webster's New World Dictionary, menjelaskan bahwa gender merupakan konsep yang melahirkan perbedaan antara laki-laki dan perempuan dilihat dari segi nilai dan tingkah laku ${ }^{11}$. Sedangkan dalam Women's Studies Encyclopedia dijelaskan bahwa gender adalah suatu konsep kultural yang berupaya membuat perbedaan (distinction) dala hal peran, perilaku, mentalitas dan karakteristik emosional antara laki-laki danperempuan yang berkembang dalam masyarakat ${ }^{12}$.

Dari kedua difinisi istilah di atas, maka peneliti menyimpulkan bahwa, gender merupakan konsep manusia berdasarkan jenis kelamin (sex) antara laki-laki dan perempuan berdasarkan biologis (anatomi) sesuai dengan kodrat dan fitrahnya masing-masing. Namun faktanya, kaum perempuan mangalami proses marginalisasi dalam segala aspek kehidupan ketimbang kaum laki-laki yang memiliki beberapa tingkat di atas perempuan dalam peran sosial.

Ketidakadilan (diskriminasi) gender lahir karena adanya truth claim atau dogma yang kemudian di doktrinkan dalam sepanjang sejarah manusia seperti: marjinalisasi, sub-ordinasi, stereotype, kekerasan, beban kerja. Dari itulah, melahirkan kesenjangan dan ketimpangan yang berasal dari struktur sosial dan anggapan bahwa sikap perempuan selalu bersifat feminin atau laki-laki bersifat maskulin bukanlah sesuatu yang mutlak kepemilikan manusia atas jenis kelamin biologisnya.

\footnotetext{
${ }^{9}$ Abd. Rachman Assegaf, Filsafat Pendidikan Islam (Jakarta: Raja Grafindo Persada, 2011), 113-114.

${ }^{10}$ Hasan Langgulung, Azas-azas Pendidikan Islam (Jakarta: Pustaka Al-Husna, 1988), 60-62.

11 Victoria Neufeldt (eds.), Webster's New World Dictionary, (New York: Webster's New World

Clevenland, 1984), hlm. 561.

${ }^{12}$ Helen Tierney (Eds.) Women's Studies Encyclopedia, Vol. I. (New York, Green Wood Press), 153.
} 
Bentuk-bentuk manifestasi ketidakadilan akibat diskriminasi gender itu meliputi: ${ }^{13}$

\section{Marjinalisasi atau Peminggiran Perempuan}

Marginalisasi berarti menempatkan atau menggeser ke pinggiran. ${ }^{14}$ Marginalisasi merupakan proses pengabaian hak-hak yang seharusnya didapat oleh pihak yang termarginalkan. Marginalisasi juga beranggapan bahwa kedudukan laki-laki jauh berada di atas perempuan dalam segala hal. Karena perempuan memiliki sifat feminim, lemah dan acap kali perempuan kurang dipromosikan seperti: ketua yayasan dalam lembaga pendidikan lebih didominasi laki-laki ketimbang perempuan, kepala intansi atau direktur mayoritas juga dari kalangan laki-laki.

\section{Sub-ordinasi.}

Sub-ordinasi merupakan pemahaman, keyakinan atau anggapan bahwa salah satu jenis kelamin dianggap lebih penting dibandingkan jenis kelamin lainnya (pandangan yang menempatkan kedudukan dan peran perempuan lebih rendah dari pada laki-laki) seperti keluarga yang menganut paham patriarki dalam memberikan perhatian lebih kepada anak laki-laki ketimbang anak perempuanya.Anak laki-laki sebagai pengganti kepala keluarga dalam mencari nafkah sedangkan anak perempuan hanya membantu pekerjaan rumah seperti memasak, mencuci dan mengurus suami dan anak pada saat nanti sudah menikah.Selain keluarga patriarki, profesi juga mengalami sub-ordinasi seperti sekretaris dan perawat yang mayoritasnya adalah perempuan sedangkan direktur, dosen, dokter, tentara, polisi mayoritasnya berasal dari kaum laki-laki.

\section{Pandangan Stereotype}

Strereotype adalah suatu pelabelan atau penandaan yang bersifat negatif terhadap jenis kelamin tertentu dan menyebabkan lahirnya ketidakadilan dan diskriminasi yang bersumber dari pandangan gender.Tugas seorang istri di rumah seperti memasak, mencuci dan mengurus kebutuhan anak dan suami merupakan contoh dari stereotypeyang sering kita jumpai dalam masyarakat pedesaan pada umumnya.Pelabelan kaum perempuan sebagai ibu rumah tangga (housewife: setelah menikah)akan menyebabkan kerugian terhadap keluarga seperti akan menyebabkan anak kurang kasih sayang - mengingat bahwa ibu merupakan pendidikan awal bagi anak-anaknya. Sementara itu, pelabelan terhadap kaum laki-laki (suami) sebagai a main breadwinner yang mempunyai tugas

\footnotetext{
${ }^{13}$ Herien Puspitawati, Makalah Pengenalan Konsep Gender, Kesetaraan dan Keadilan Gender.Oleh: (Pusat Kajian Gender dan Anak-LPPM-IPB dan Tim Pakar Gender Pusat Kementerian Pendidikan dan Kebudayaan RI) Disampaikan Pada: Rapat Koordinasi Kesetaraan Gender se Wilayah 1 Bogor Kamis, 22 Maret, 2012.

${ }^{14}$ Murniati, Perempuan Indonesia dalam Perspektif Sosial, Politik, Ekonomi, Hukum dan HAM.(Magelang: Indonesiatera, 2004), xx.
} 
untuk melaksanakan kewajibannya untuk menafkahi anak dan istrinya.Berdasarkan pelabelan di atas, kerja keras seorang istri di rumah kadangkala tidak dianggap bekerja karena pekerjaannya tidak berwujud materi atau uang — padahal kerja keras istri mulai dari pagi sampai malam dan pagi lagi adalah kerja yang bisa dikatakan kerja 24 jam non-stop.

\section{Kekerasan}

Kekerasan atau violence adalah suatu serangan terhadap fisik dan mental psikologi seseorang, seperti perkosaan, pemukulan, dan penyiksaan (kekerasan fisik), pelecahan seksual, ancaman dan paksaan (kekerasan yang bersifat non fisik). Kedua kekerasan tersebut bisa terjadi seperti Kekerasan Dalam Rumah Tangga (KDRT) yang diawali dari pertengkaran mulut, pemukulan suami terhadap istri dan anaknya bahkan pembunuhan karena beberapa kasus asusila (amoral) seperti istrinya selingkuh, anak mengandung di luar nikah, anak tidak naik kelas dan kasus yang lainnya.

\section{Beban Kerja}

Beban kerja adalah peran dan tanggung jawab seseorang dalam melakukan berbagai jenis kegiatan sehari-hari dan memberatkan seseorang.Beban kerja ganda merupakan bentuk diskriminasi dan ketidakadilan gender.Seorang ustadzah (yang sudah menikah) memiliki beban kerja ganda atau 2 profesi yaitu sebagai istri dan guru. Sebagai istri, dia harus memasak, mencuci dan mengurus serta mengatur semua pekerjaan rumahnya; dan pada satu sisi yang lain dia sebagai guru yang harus mengajar, mendidik muridnya di sekolah. Sepintas kedua profesi yang melekat pada satu diri individu merupakan pengabdian dan pengorbanan yang mulia (altruism) yang nanti di akhirat mendapatkan balasan yang setimpal.Namun demikian harus ada suatu batas dari pengorbanan ini, karena pengorbanan yang tanpa batas berarti menjurus kepada ketidakadilan.

Kelima manfestasi di atas merupakan ketidakadilan gender yang acap kali oleh sebagian umat Islam dianggap sebagai perbedaan mengenai kesetaraan gender antara laki-laki dan perempuan. Dalam surat al-Nisā' (4): 34 yang kemudian dijadikan landasan berpikir tanpa ditafsiri secara mendalam dapat menyebabkan penafsiran yang mengarah pada sosiokultural dengan anggapan bahwa perempuan adalah sosok yang tidak berharga, sub-ordinat dari laki-laki, stereotype dengan cara mengambil hak, merampas, menindas dan melahirkan kekerasan (violance) - yang diawali dengan memarginalkan perempuan dalam segala aspek kehidupan manusia.

\section{Rekontruksi Keadilan Gender dalam Pendidikan Islam}

Dalam memposisikan hakikat dan eksistensi perempuan, kita dapat merujuk pada pengalaman di masa Nabi Muhammad saw yag telah berupaya memaksimalkan dalam mewujudkan gender equality, akan tetapi kultur masyarakat pada masa ituu belum kondusif untuk mewujudkan hal 
itu. $^{15}$ Namun, ketika dilihat sejarah perkembangan karir kenabian Muhammad, maka kebijakan rekayasa sosialnya semakin mengarah kepada prinsip-prinsip kesetaraan gender yang telah tersurat maupun tersirat dalam al-Qur'an: ${ }^{16}$

a. Perempuan bisa mendapatkan harta warisan atau hak-hak kebendaan (pada zaman jahiliyah, perempuan tidak mendapatkan warisan bahkan setiap bayi perempuan yang baru lahir langsung dibunuh karena dianggap sebagai aib keluarga) (QS. al-Nisā' [4]:12).

b. Laki-laki boleh berpoligami sekalipun dengan syarat yang sangat ketat (Q S. al-Nisā' [4]:3).

c. Perempuan boleh menjadi saksi meskipun dalam beberapa kasus(Q. S. al-Baqarah/2:228 dan QS. al-Nisā' [4]:34). ${ }^{17}$

d. Perempuan boleh (aktif) menekuni berbagai profesi (QS. al-Taubah [9]:71). Dalam dunia politik misalnya: Fāttimah binti Rasulullah, 'A'ishah binti Abū Bakar, 'Âtika binti Yazìid ibn Mu'āwiyah, Ummu Salamah binti Ya'qūb, al-Khayzaran binti 'Ațo', dan lain sebagainya ${ }^{18}$.Dalam bidang ekonomi perempuan bebas memilih pekerjaan yang halal, baik di dalam atau di luar rumah, mandiri atau kolektif, di lembaga pemerintah atau swasta, selama pekerjaan itu dilakukan dalam suasana terhormat, sopan, dari tetap menghormati ajaran agamanya. Hal ini dibuktikan oleh sejumlah nama penting seperti Khādijah binti Khuwaylid (istri Nabi) yang dikenal sebagai komisaris perusahaan, Zaynab binti Jahsh, profesinya sebagai penyamak kulit binatang, Ummu Salim binti Malhan yang berprofesi sebagai tukang rias pengantin, istri Abdullah ibn Mas'ùd dan Qilat Ummi Bani Anmar dikenal sebagai wiraswastawan yang sukses, al-Shifā' yang berprofesi sebagai sekretaris dan pernah ditugasi oleh Khalifah 'Umar sebagai

\footnotetext{
${ }^{15}$ Musdah Mulia, Islam Menggugat Poligami (Jakarta: Citra Media, 2004), 47.

${ }^{16}$ Istilah gender dalam Al-Qur'ân dapat dipahami melalui nama-nama atau simbolsimbol yang sering digunakan al-Qur'an dalam mengungkapkan jenis kelamin seseorang. Istilah-istilah gender yang sering digunakan dalam al-Qur'an antara lain: al-rajul/al-rijāl dan al-mar'ah/alnisä',al-dhakar dan al-unthā, termasuk gelar status laki-laki dan perempuan seperti, al-zawj dan alzawjah,

al-abdan al-um, al-akh dan al-ukht, aljad dan al-jaddah, al-muslimūn dan almuslimāt, almu'minūn dan al-mu'mināt, serta damir mudhakkar dan mu'annath, yang digunakan al-Qur'an

terhadap laki-laki dan perempuan. Persoalan kebahasaan yang berhubungan dengan istilah tersebut, lihat Nasaruddin Umar, Argumen Kesetaraan Gender; Perspektif al-Qur'an (Jakarta: Paramadina, 1999), 143-193.

17 Amina Wadud Muhsin, Wanita Dalam Al Qur'an, diterjemahkan oleh Yaziar Radianti (Bandung: Pustaka, 1994), 117.

${ }^{18}$ Haya Binti Mubârak al-Barik, Ensiklopedi Wanita Muslimah (Jakarta: Dār alFalāh, 1419 H), 189.
} 
petugas yang menangani pasar kota $\operatorname{Madinah}^{19}$.Dalam bidang pendidikan tidak perlu diragukan lagi, al-Qur'an dan Hadis banyak memberikan pujian kepada perempuan yang mempunyai prestasi dalam ilmu pengetahuan. Al-Qur'an menyinggung sejumlah tokoh perempuan yang berprestasi tinggi, seperti Ratu Balqis, Maryam, istri Fir'ūn, dari sejumlah istri Nabi. Dalam suatu riwayat disebutkan bahwa Nabi pernah didatangi kelompok kaum perempuan yang memohon kesediaan Nabi untuk menyisihkan waktunya guna mendapatkan ilmu pengetahuan.

e. Islam adalah agama ke-Tuhanan sekaligus agama kemanusiaan dan kemasyarakatan (QS. Ali Imrān [3]: 112). Dalam pandangan Islam, manusia mempunyai dua kapasitas, yaitu sebagai hamba ('ābid) dan sebagai representatif Tuhan (khalifah), tanpa membedakan jenis kelamin, etnik, dan warna kulit (QS. Al-Hujurāt [49]: 13).

Berkaitan dengan tugas tersebut maka perlu diadakan pembukaan ruang keadilan gender melalui optimalisasi proses pendidikan Islam. Optimalisasi yang dimaksud adalah upaya untuk mengikis bias gender yang terjadi dalam segala proses pendidikan Islam. Merujuk pada tujuan pendidikan Islam sebagai langkah dan usaha preventif dan mengotptimalkan dengan cara merumuskan kembali tujuan pendidikan yang tidak mengarah kepada bias gender yaitu dengan lebih memprioritaskan kepada:

a. Meneguhkan nilai-nilai kemanusiaan

b. Mengembangkan ilmu pengetahuan dan teknologi

c. Membentuk Kesadaran Individu yang Mempunyai Kepakaan Sosial. ${ }^{20}$

Adapun buku-buku dari tokoh feminis Islam tersebut misalnya, "Women and Religion: An Islamic Prespective" karya dari Rifa'at Hassan, "Women and Islam"karya Fatima Mernissi, "Women in the Qur'an"karya Amina Wadud. ${ }^{21}$ Dalam kalangan tafsir seperti Ibnu Katsir, Muhammad Abduh, al-Qurthubi, az-Zamakhsharīi, al-Tabātabā', 'ì, dan al-Hijāzì terkait dengan tafsir QS.Al-Nisā'[4]: ayat 3 tentang istilah qawwām. Para ahli tafsir menyatakan bahwa qawwām berarti pemimpin, penanggung jawab, pengatur, pendidik.Kategori-kategori ini sebenarnya tidak menjadi persoalan serius, sepanjang ditempatkan secara adil dan tidak disadari oleh

${ }^{19}$ Qāsim Amīn, Tahrīir al-Mar'ah dalam Hamka Hasan, Tafsir Gendera: Studi Perbandingan Antara Tokoh Indonesia dan Mesir (Badan Litbang dan Diklat Departemen Agama RI, 2009), 55.

${ }^{20}$ Menurut Ahmad Tafsir, seorang insan kamil muslim yang sempurna adalah sosok yang memiliki jasmani sehat dan kuat, akal yang cerdas dan pandai serta hati yang senantiasa bertaqwa kepada Allah Lihat dalam Ahmad Tafsir, Ilmu Pendidikan dalam Perspektif Islam (Bandung: Rosdakarya, 1994), 50.

${ }^{21}$ Siti Ruhaini Dzuhayatin, Rekonstruksi Metodologis Wacana Kesetaraan Gender dalam Islam dalam Membincangkan Feminisme (Surabaya: Risalah Gusti, 2002), 10-11. 
pandangan deskriminatif.Akan tetapi, para ahli tafsir berpendapat bahwa superioritas laki-laki ini adalah mutlak. Seperioritas ini diciptakan Allah swt, sehingga tidak akan pernah berubah. Kelebihan laki-laki dan perempuan sebagaimanya dinayatakan dalam QS.Al-Nisā[4] ayat 3 tersebut, oleh para penafsir al-Qur'an dikatakan karena akal dan fisiknya. Al-Rāzi dalam tafsirnya menyatakan bahwa kelebihan laki-laki dan perempuan meliputi dua hal: ilmu pengetahuan/pikiran/akal dan kemampuan. Artinya akal dan pengetahuan laki-laki melebihi akal perempuan, dan bahwa untuk pekerjaan-pekerjaan keras laki-laki lebih sempurna ${ }^{22}$.

Al-Qur'an merupakan kitab suci dan huda li al-nās untuk mencapai kebahagian di dunia dan akhirat. Ajaran dan nilai-nilai yang terkandung di dalamnya menjadikan manusia dalam berinteraksi sosial kemasyarakatan antara laki-laki dan perempuan dalam pandangan egaliter. Konsep gender dalam al-Qur'an, sebagaimana yang dijelaskan oleh Nasaruddin Umar, prinsip-prinsip kesataraan gender berdasarkan ayat berikut:

Pertama, prinsip kesetaraangender mengacu persamaan laki-laki dan perempuan sebagai 'abdullah.Dalam hal peribadatan, Allah mewajibkan laki-laki dan perempuan untuk menyembah-Nya. Allah tidak menilai dan mengklaim bahwa ibadah laki-laki lebih diterima ketimbang perempuan atau sebaliknya, akan tetapi Allah memberikan penjelasan, siapapun itubaik laki-laki ataupun perempuan kalau ibadahnya sholeh dan sholehah pasti akan mendapatkan pahala dan balasannya nanti adalah surga dan dijelaskan dalam, sebagaimana yang dijelaskan dalam firman-Nya:

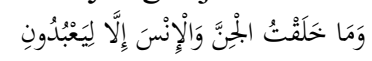

"Dan tidaklah Aku menciptakan jin dan manusia kecuali untuk menyembah-Ku."(QS. al-Dhāriyāt [51]: 56).

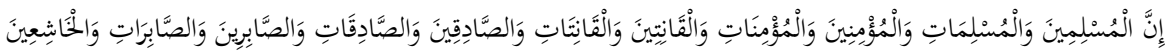

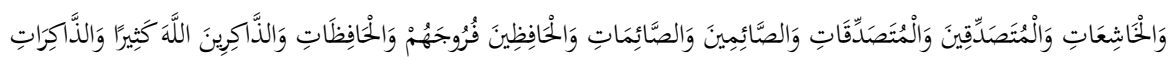

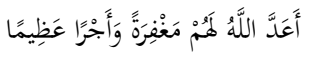

"Sesungguhnya laki-laki dan perempuan yang muslim, laki-laki dan perempuan yang mukmin, laki-laki dan perempuan yang tetap dalam ketaatannya, laki-laki dan perempuan yang benar, laki-laki dan perempuan yang sabar, laki-laki dan perempuan yang khusyuk, laki-laki dan perempuan yang bersedekah, laki-laki dan perempuan yang berpuasa, laki-laki dan

\footnotetext{
${ }^{22}$ Edi Susanto, Dimensi Studi Islam Kontemporer (Jakarta: Prenadamedia Group, 2016), 158-159. Lebih jelasnya dalam kelebihan laki-laki dan perempuan silahkan periksa Fakhr al-Din al-Razi, Tafsir al-Kabir, Juz X (Beirut: Dār al-Hayat al-Turāth al-Arabīi, 1990), 88 .
} 
perempuan yang memelihara kehormatannya, laki-laki dan perempuan yang banyak menyebut (nama) Allah, Allah Telah menyediakan untuk mereka ampunan dan pahala yang besar, yang dimaksud dengan muslim di sini ialah orang-orang yang mengikuti perintah dan larangan pada lahirnya, sedang yang dimaksud dengan orang-orang mukmin di sini ialah orang yang membenarkan apa yang harus dibenarkan dengan hatinya." (QS. Al-Ahzāb [72]: 35).

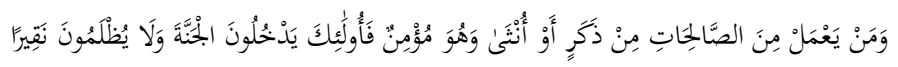

"Barangsiapa yang mengerjakan amal-amal saleh, baik laki-laki maupun wanita sedang ia orang yang beriman, maka mereka itu masuk ke dalam surga dan mereka tidak dianiaya walau sedikitpun"(QS.Al-Nisā[4]: 124).

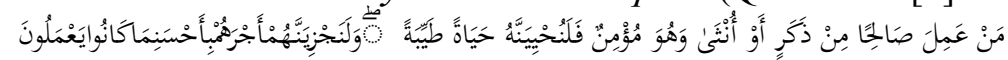

"Barangsiapa yang mengerjakan amal saleh, baik laki-laki maupun perempuan dalam keadaan beriman, maka sesungguhnya akan Kami berikan kepadanya kehidupan yang baik dan sesungguhnya akan Kami beri balasan kepada mereka dengan pahala yang lebih baik dari apa yang telah mereka kerjakan.’(QS. Al-Nahl [16]: 97).

Kedua, kesetaraan gender sebagai khalifah (QS.Al-Baqarah [2]: 30). Pada ayat ini Allah tidak menunjukkan kepada salah satu jenis kelamin yang berasal dari bangsa, suku atau kelompok tertentu, melainkan Allah menciptakan manusia secara universal sebagai khalifah (pemimpin).Ketiga, surat al-Nahl ayat 97 tentang kesetaraan gender dalam meraih prestasi dalam kehidupannya. ${ }^{23}$

Beberapa ayat di atas, menjelaskan bahwa Islam menjunjung tinggi kesataraan gender dan menolak tindakan diskriminatif yang tidak dibenarkan oleh dasar ajaran Islam. Oleh karena itu, yang menjadi ukuran mulia tidaknya manusia dan tinggi atau rendahnya derajat manusia hanyalah ketakwaannya sebagai kunci mengharap ridha-Nya.Karena pada hakikatnya, agama diperuntukkan bagi umat manusia sebagai kitab suci umatnya yang tidak memandang perbedaan dalam bentuk apapun melainkan semata-mata beribadah kepada-Nya dan mengharap ridha-Nya.

Untuk mencapai kesetaraan gender dalam pendidikan Islam, menurut penulis berdasarkan al-Qur'an dan kajian literature di atas, maka langkah yang perlu dilakukan adalah:

1. Adanya pengajian tafsir al-Qur'an, kitab kuning maupun ceramah agama yang membahas tentang kesataraan gender yang sebenarnya, sehingga masyarakat awam dan masyarakat yang minim tentang agama mengetahui hakikat gender dalam perspektif Islam, sehingga tidak ada diskriminasi dalam keluarga, pendidikan dan masyarakat.

${ }^{23}$ Nasaruddin Umar, Argumen Kesetaraan Gender, 252-253. 
2. Dalam keluarga, orang tua harus memberikan kepada anaknya sesuai dengan kemampuannya masing-masing tanpa ada unsur paksaan dalam memilih pendidikannya, dengan mempertimbangkan kemampuan ekonomi keluarga dan kecerdasan anaknya.

3. lembaga pendidikan memberikan kurikulum berbasis gender dalam rangka mencegah pelecehan seksual dan kekerasan terhadap perempuan sebagai langkah preventif yang dapat melahirkan kejahatan dan kriminal di masyarakat.

\section{Epilog}

Rekonstruksi keadilan gender dalam pendidikan Islam merupakan upaya dalam mengingatkan kembali umat Islam bahwa laki-laki dan perempuan adalah sama dalam pandangan Allah swt, hanyalah keimanan yang membedakan diantara keduanya. Pendidikan Islam mempunyai tugas meluruskan pemahaman yang salah umatnya tentang ilmu pengetahuan dan paham yang terjadi dalam lingkungannya baik dalam keluarga, masyarakat, berbangsa dan bernegara (hablu min al-nās) dan dalam aspek ibadah dalam kehidupannya sehari-hari (hablu min Allāh). Upaya yang dapat dilakukan dalam meng-rekonstruksi keadilan gender dalam pendidikan Islam dapat dimulai dari: pertama, mengadakan pengajian tafsir al-Qur'an, kitab kuning maupun ceramah agama tentang kesetaraan dan keadilan gender. Kedua, Dalam keluarga, orang tua harus adil, memberikan hak dan kewajibannya tanpa kekerasan, marjinal, sub-ordinasi, beban kerja dan stereotype.Ketiga, lembaga pendidikan memberikan kurikulum berbasis gender dalam rangka mencegah pelecehan seksual dan kekerasan terhadap perempuan sebagai langkah preventif yang dapat melahirkan kejahatan dan kriminal di masyarakat.

\section{Daftar Pustaka}

Al-Barik, Haya Binti Mubârak. Ensiklopedi Wanita Muslimah. Jakarta: Dār al-Falāh, $1419 \mathrm{H}$.

Al-Rasyidin. Falsafah Pendidikan Islami: Membangun Kerangka Ontologi, Epistimologi dan Aksiologi Praktik Pendidikan. Bandung: Citapustaka Media Perintis, 2008.

al-Rāzì, Fakhr al-Dīn. Tafsìr al-Kabìir, Juz X. Beirut: Dār al-Hayat al-Turāth al-Arabī, 1990.

Aly, Hery Noer. Ilmu Pendidikan Islam. Jakarta:Logos Wacana Ilmu, 1999.

Amìn, Qāsim. Tahrìr al-Mar'ah dalam Hamka Hasan, Tafsir Gendera: Studi Perbandingan Antara Tokoh Indonesia dan Mesir. Badan Litbang dan Diklat Departemen Agama RI, 2009.

Assegaf, Abd. Rachman. Filsafat Pendidikan Islam. Jakarta: Raja Grafindo Persada, 2011. 
Dzuhayatin, Siti Ruhaini. Rekonstruksi Metodologis Wacana Kesetaraan Gender dalam Islam dalam Membincangkan Feminisme. Surabaya: Risalah Gusti, 2002.

Herien Puspitawati, Makalah Pengenalan Konsep Gender, Kesetaraan dan Keadilan Gender Oleh: (Pusat Kajian Gender dan Anak-LPPM-IPB dan Tim Pakar Gender Pusat Kementerian Pendidikan dan Kebudayaan RI) Disampaikan Pada: Rapat Koordinasi Kesetaraan Gender se Wilayah 1 Bogor Kamis, 22 Maret 2012.

Ilyas. Feminisme dalam Kajian Tafsir Al-Qur'an Klasik dan Kontemporer. Yogyakarta: Pustaka Pelajar, 1998.

Langgulung, Hasan. Azas-azas Pendidikan Islam. Jakarta: Pustaka AlHusna, 1988.

Mājah, Sunan Ibnu. Kitab al-'Ilmi, Bab Keutamaan Ulama' dan Anjuran Mencari Ilmu. Bentuk-bentuk Dar Al Fikri, 2001.

Muhsin, Amina Wadud. Wanita Dalam Al Qur'an. Bandung: Pustaka, 1994.

Mulia, Musdah. Islam Menggugat Poligami. Jakarta: Citra Media, 2004.

Murniati. Perempuan Indonesia dalam Perspektif Sosial, Politik, Ekonomi, Hukum dan HAM. Magelang: Indonesiatera, 2004.

Mursi, Muhammad Munir.al-Tarbiyah al-Islamiyah Usuluha wa Tatawwuruha fi al-Bilad al-Arabiyah, Cet. IV. Mesir: Dar al-Ma'arif, 1987.

Nata, Abuddin. Pemikiran Para Tokoh Pendidikan Islam: Kajian Filsafat Pendidikan Islam. Cet. II; Jakarta: PT Raja Grafindo Persada, 2001.

Neufeldt (eds.), Victoria. Webster's New World Dictionary. New York: Webster's New World Clevenland, 1984.

Susanto, Edi. Dimensi Studi Islam Kontemporer. Jakarta: Prenadamedia Group, 2016.

Syah.Muhibbin. Psikologi Pendidikan dengan Pendekatan Baru. Bandung: PT.Remaja Rosda Karya, 2011.

Tafsir, Ahmad. Ilmu Pendidikan dalam Perspektif Islam. Bandung: Rosdakarya, 1994.

Tierney (Eds.), Helen. Women's Studies Encyclopedia, Vol. I. New York, Green Wood Press.

Umar, Nasaruddin. Argumen Kesetaraan Gender; Perspektif Al-Qur'an. Jakarta: Paramadina, 1999. 